\title{
Mary Whitehouse og autentisk bevægelse
}

\section{Af Pia Houmark}

\section{Mary Whitehouse}

»I don't care what the body does! Heresy! I don't care!...What I am looking at is the physical movement as a revelation, as a show of the inner thing. Therefore I am not saying: »The shoulders are up, the mouth is this way... «I take that in but it's minor. What I am looking at is the psychic attitude displayed by the physical movement ${ }^{1}{ }^{1}$

Ordene er sagt af een af danseterapiens pionéerer Mary Starks Whitehouse (19111979), som kombinerede moderne dans og jungiansk psykologi i en danseterapeutisk model med titlen »Autentisk Bevægelse «. ${ }^{2}$

Hun var stort set ligeglad med, hvad danserne gjorde med kroppen og hvordan bevægelserne tog sig ud. Hun interesserede sig mere for, hvordan fysisk bevægelse kunne bruges til at forstå danserens indre, psykiske liv og hvordan dét, at udtrykke sit indre liv i dans og bevægelse kunne bruges som et terapeutisk middel i menneskelige udviklingsprocesser.

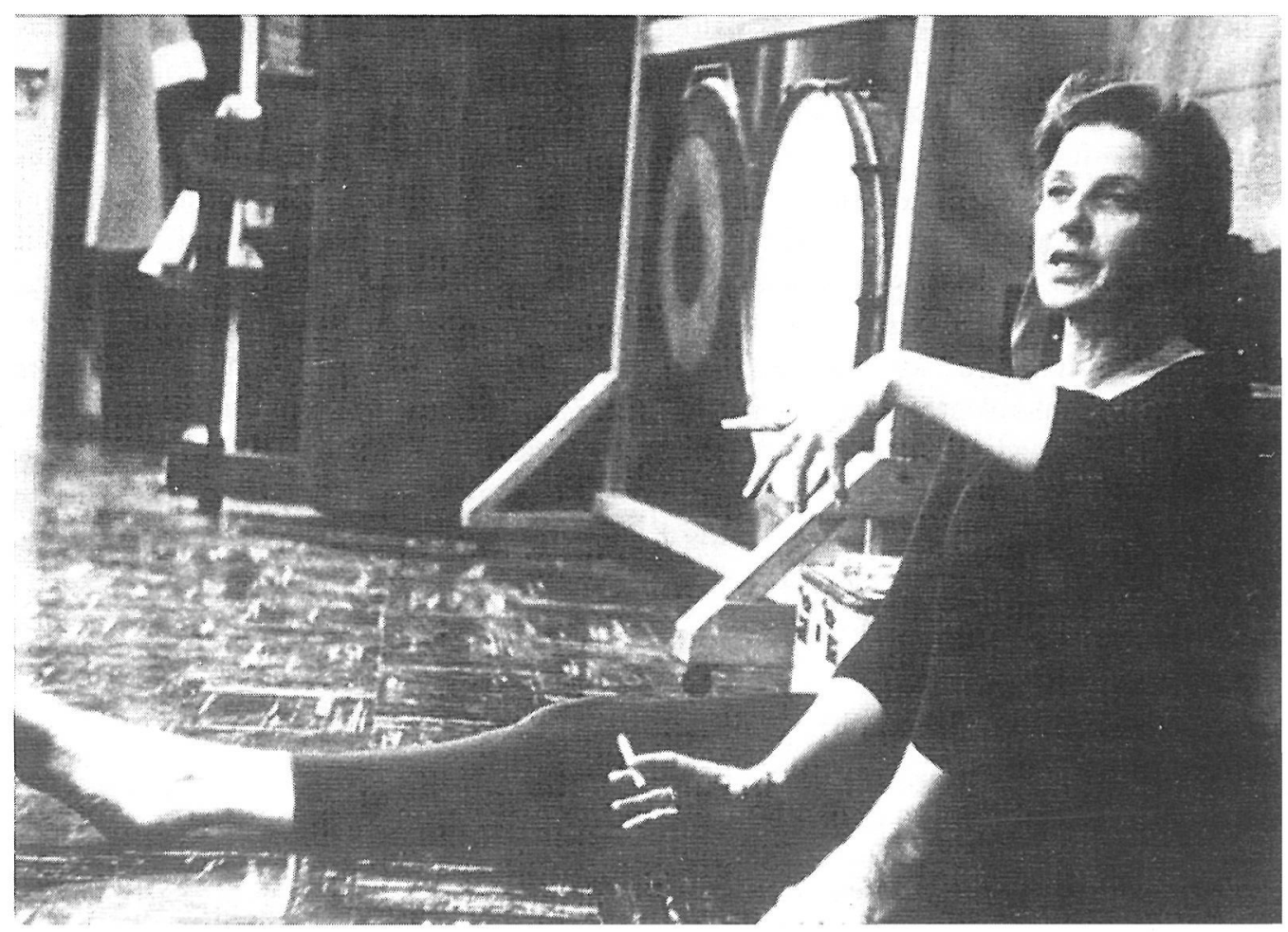

Mary Whitehouse i sit dansestudie i Los Angeles (fra Levy, 1988) 


\section{Rфdderne i moderne dans}

Mary Whitehouses arbejde med bevægelse var dybt influeret af Mary Wigman(18861973), som var een af hovedfigurerne i udviklingen af den moderne, ekspressive dans i Europa, den såkaldte »Ausdruckstanz « ${ }^{3}$.

Igennem flere år var Whitehouse elev på Wigmans skole i Dresden og senere også professionel danser $\mathrm{i}$ hendes kompagni. Hun opfattede Wigman's dans som forløberen for danseterapien og sagde om sine erfaringer dér:

»The Wigman training prepared me for a particular approach although I did not know it at the time; it made room for improvisation, placing value on the creativity of the people moving. It assumed that you would not be learning to dance if you had nothing to say « ${ }^{4}$

Hos Wigman havde Whitehouse arbejdet med expressive improvisationer som en metode til at komme i kontakt med indre impulser og til at lade sig bevæge af impulserne uden bevidst at gribe ind i bevægelsens form og forløb.

I modsætning til den klassiske ballets perfektionering af bevægelsens ydre form via den bevidste kontrol over kropsudfoldelsen focuserede Wigman på at slippe kontrollen og tillade de kulturelt set mest tabuerede og mørkelagte sider af mennesket at komme til udtryk i dansen. - Og dèt med en kraft og autencitet, som kan fornemmes i dansekritikeren John Martins' opfattelse af Wigmans expressive dans som den sublime udvikling af moderne dans:

»At its highest point of development we find the socalled expressionistic dancing with Mary Wigman as an outstanding practioner. This class of dance is in effect the modern dance in its purest manifestation. The basis of each composition...lies in a vision of something in human experience which touches the sublime. Its externalization... comes not by intellectual planning but by feeling through with a sensitive body. The result is the appearance of entirely authentic movements which are as closely allied to the emotional experience as an instinctive recoil is to an experience of fear $\ll^{5}$

Billedet af Wigmans danse som »autentiske bevægelser« blev også opsnappet af Whitehouse og »Autentisk Bevægelse«, blev dèt navn, hun senere valgte at give sit eget terapeutiske arbejde med at styrke individets kapacitet for at kontakte indre, ubevidste impulser og at tillade impulserne at komme autentisk til udtryk i bevægelse. Men danseterapien lå endnu et stykke ude $\mathrm{i}$ Whitehouses fremtid.

Efter at være kommet hjem fra Tyskland begyndte Whitehouse i starten af 1950'erne at undervise i moderne dans samtidig med at hun dansede hos een af pionéererne i den amerikanske moderne dans, Martha Graham(1894-1989). Herfra tog hun især Grahams gulvøvelser til sig og gjorde det til en fast komponent i sin egen dans og i sin danseundervisning.

Dans, performing og undervisning i dans var igennem en årrække en integreret del af Mary Whitehouse's liv og et middel til at forsørge sig selv og sine to små børn, som hun var blevet alene med efter en skilsmisse. I tilbageblik på udviklingen af sin danseterapeutiske metode beskriver hun, hvordan skilsmissen havde gjort undervisningen i dans til en forpligtende $\varnothing$ konomisk nødvendighed, men samtidig også havde åbnet for nye livsperspektiver, der involverede nye perspektiver på dansen ${ }^{6}$.

Det var disse perspektiver, der udmøntede sig $\mathrm{i}$ en anden måde at arbejde med bevægelse, som i højere grad end scenedansen inkluderede danserens sjæleliv og personlige udvikling. I sit dansestudie i Los Angeles begyndte Whitehouse efterhånden at arbejde terapeutisk med både grupper og individuelle klienter, ofte aktive eller tidligere professionelle dansere, der allerede 
var vant til at arbejde med kroppen igennem dans og bevægelse ${ }^{7}$. Navnet på metoden kom dog først senere - for Whitehouse var i begyndelsen ikke helt klar over, hvad det egentlig var der foregik $i$ hendes danselokale...

\section{Fra danser til danseterapeut}

»Odd, but I turned into a dance therapist without realizing it, simply because no such thing existed when I started. In teaching dance, I was dimly aware of a different and new element. People would come up to me at the end of class and ask, »What is this?«... I would ask, »Well what do you think it is - what do you get out of it? «. The answer always had as much confusion as I had myself. It took a long time before our work together came to be accepted by us both as more, and less, than dance. $\ll^{8}$

Whitehouses måde at arbejde med dans udviklede sig gradvist væk fra den kunstneriske form, hun havde oplevet hos Wigman og Graham.

Efterhånden fik hun den holdning, at scenedansen var for resultatorienteret og at gentagelserne og timingen involveret $\mathrm{i}$ den nødvendige perfektion af bevægelsesudtrykket uundgåeligt fjernede opmærksomheden fra det enkelte nu's enestående oplevelses-kvaliteter under bevægelsesproces$\operatorname{sen}^{9}$.

I en artikel $»$ Reflections on a metamorphosis« fra 1969 beskriver Whitehouse sin egen udvikling fra danser til danseterapeut som sammenflettet med hendes personlige erfaringer med den jungianske psykologi. Foranlediget af en følelsesmæssig krise i forbindelse med sin skilsmisse var hun begyndt at gå i jungiansk analyse, som hun senere fulgte op og fordybede med studier ved C.G.Jung-instituttet i Zürich.

Whitehouse beskriver i artiklen, hvordan hendes bevægelser og opfattelse af bevægelse langsomt havde undergået en forandring - en metamorfose - og var blevet noget andet, både mere og mindre, end moderne dans. MINDRE - fordi perfektionen af sceneudtrykket ikke længere var et mål i hendes egen danseundervisning - og ME$\mathrm{RE}$ - fordi hun nu opfattede arbejdet med bevægelse som en dybdepsykologisk udviklingsproces, der først og fremmest handlede om at frigøre dét, hun kaldte en »naturlig impuls« $\mathrm{i}$ danserens krop:

»...there was something in people that danced, a natural impulse, unformed and at first even fugitive. If I could find ways of releasing it, if I could come to grips with what interfered and prevented its expression, I might find the beginning of what my discovery meant $\ll .{ }^{10}$

Ligesom een af danseterapiens store foregangsfigurer, Isadora Duncan (1878-1927), mente Whitehouse også i kroppens bevægelser at kunne se, hvordan danserens naturlige impulser kunne være bundet, hæmmet og hindret eller komme frit og harmonisk til udtryk i bevægelserne. Og som sine personlige læremestre $i$ den moderne dans søgte Whitehouse også friheden og var nysgerrig efter at få greb om, hvad det var, der hindrede mennesket $\mathrm{i}$ at udtrykke sig $\mathrm{i}$ overensstemmelse med de naturlige impulser, som hun mente dansede i dybet af kroppen.

Men - hvor både Duncan, Graham og Wigman som kunstnere havde arbejdet fra scenen og derfra søgt at frigøre deres indre impulser $\mathrm{i}$ en dionysisk frihedsdans mod samtidens kulturskranker, trak Whitehouse frihedskampen ned fra scenen og helt ind $\mathrm{i}$ den enkeltes tilværelse.

Friheden opstod for Whitehouse lige dér, hvor dét, der hindrede den naturlige impuls $i$ at komme til udtryk blev integreret $\mathrm{i}$ bevidstheden - og lige dér blev hun danseterapeut og ikke danselærer. Hun lærte ikke mere sine elever at danse - hun støttede mennesker i at åbne sig for en indre vækstproces gennem bevægelse: 
»Whatever it was we were travelling away from dance. I had to call it movement, in order to find what it was that truly moved people...I was finding more and more that the things happening in classes allowed pieces of movement, not dances...moments of movement that allowed people to discover something different for and about themselves - not because I taught it to them but because I made an opening for that discovery ${ }^{11}$

Herfra omtalte Whitehouse ikke mere sine elever med det kunstnerisk ladede ord »dansere « men derimod som »bevægere«. Og i stedet for »dans « talte hun om »bevægelse « - Autentisk Bevægelse«:

»The title came very gradually, year after year. It distinguished to me what I was doing as opposed to dance or therapy. I was really looking for a way to help people to turn back to themselves and find the layer within layer within themselves rather than learning how to do something ${ }^{12}$

\section{Indefra ud}

I forlængelse af sit syn på bevægelse som en fysisk åbenbaring af det indre psykiske liv søgte Whitehouse en forståelse af bevægelsernes udspring i danserens indre:

»...Where does movement come from? It originates in ... a specific inner impulse having the quality of sensation. This impulse leads outwards into space so that movement becomes visible as physical action $\ll{ }^{13}$

De fysiske bevægelsers udspring i en specifik indre impuls med retning indefra ud var i Whitehouses danseterapi et kardinalpunkt med dyb forankring i den moderne dans' opgør med den klassiske ballet - et opgør, der som noget helt cenralt havde handlet om at vende opmærksomheden bort fra bevægelsernes ydre form og IND I danserens indre liv.

Selvom denne indre impuls virkelig var helt fundamental $i$ »Autentisk Bevægelse« præciserede Whitehouse aldrig hverken arten eller kvaliteten af impulsen eller hvor- dan det kan være, at den bevæger sig »indefra og ud «. Dette kan synes en besynderlig undladelse, men kan måske forstås på baggrund af den selvforståelse, der var inkluderet i den moderne dans' brug og opfattelse af bevægelse som en expressiv proces - $\mathrm{i}$ den helt bogstavelige betydning, at noget bliver trykt ud indefra og altså indlysende må bevæge sig i den expressive retning indefra ud.

\section{Aktiv Imagination}

$\gg$ The use of Active Imagination in movement is peculiarly valuable. Every possible way I could devise to involve people in their own fantasies and images, even moving out their dreams, provides raw material for understanding themselves $\ll .{ }^{14}$

Dén psykoterapeutiske metode, som Whitehouse var inspireret af, var en form for fri fantaseren, som Jung kaldte for Aktiv Imagination.

Metoden har ligheder med de freudianske »frie associationer «, men adskiller sig derved, at Freud i arbejdet med drømme tilstræbte en »frit flydende opmærksomhed « hos analysanden, som uden censur skulle meddele sin spontane associationer på enkeltelementerne i drømmene uden at fastholde dén affekt eller forestilling, der havde været udgangspunkt for drømmen. Dette mente Freud førte analysanden tilbage til drømmebilledernes oprindelige udspring $\mathrm{i}$ de fortrængte komplekser i det ubevidste, som Freud så kunne sætte sammen til en tydning, der kunne indkredse fortrængningens årsag. ${ }^{15}$

Jung mente godt nok også, at associationerne førte drømmeren til dennes komplekser, men dem kunne man, mente Jung, lige så godt komme til ved at associere til et uforståeligt russisk eller indisk jernbaneskilt. Og dette ville alligevel ikke føre til en forståelse af drømmeindholdets fremadret- 
tede mening, som for Jung var langt vigtigere end Freuds bagudrettede årsagsforklaringer. ${ }^{16}$

Det afgørende i Jungs metode var, at han focuserede på jeg'ets aktive medvirken aktive imagineren/fantaseren - som betød, at drømmeren med sit bevidste jeg kunne gå aktivt i dialog med figurerne i drømmene. ${ }^{17}$ Han tilstræbte derfor ikke en frit flydende opmærksomhed hos analysanden, men derimod en aktivt arbejdende opmærksomhed, som ikke alene skulle føre analysanden til men også igennem komplekserne.

Jung brugte her ikke alene verbale associationer, men enhver art af kreativ virksomhed: tegning, maling, modellering af billeder, dans, »sandplay« m.m., der kunne give de indre ubevidste processer et ydre udtryk, som var til at bearbejde i bevidstheden. ${ }^{18}$ Aktiv imagination involverer på denne måde en toleddet proces, hvor det første led består i 1) at man åbner sig for det ubevidste og giver fantasien frit $l \varnothing b$ og det andet i 2) at man samtidig fastholder en vågen, koncentreret, aktiv opmærksomhed, som kan give de ubevidste processer et ydre udtryk.

\section{Aktiv imagination i bevagelse}

I sin jungianske drømmeanalyse havde Whitehouse oplevet, hvordan det analytiske arbejde med at komme i kontakt med egne, indre psykiske processer var een lang opdagelse af det ubevidstes levende realitet i kroppen.

Som danseterapeut arbejdede hun med aktiv imagination gennem expressive improvisationer, som hun mente var en særlig velegnet måde at undgå egoets censur af det ubevidste og samtidig at lade det ubevidste fă et fysisk, synligt udtryk, hvis in- dre mening på denne måde kunne gøres tilgængeligt for bevægeren:

»One reason that the movement form of Active Imagination is so valuable is that it is extremely difficult to censor. One moves before one knows what is happening... Movement, like dreams, is ephemeral, one cannot will to repeat it exactly. Spontaneous movement shows that inner processes take physical form and can be seen, their meaning apprehended, their value received by the person out of whose body the movement comes ${ }^{19}{ }^{19}$

En afgørende forskel på de indre billeder, der spontant dukker op i drømme og de fysiske bevægelser, der spontant dukker op i en improvisation er netop, at hvor drømmebillederne kun kan ses og opleves af drømmeren selv, da kan bevægelserne både opleves af dén, der bevæger sig og ses af andre i omverden.

I den verbale drømmeanalyse må klienten gå via sproget for at formidle sine indre impulser, hvorimod dette mellemled er unødvendigt i den expressive improvisation. I bevægelsen kommer impulsen direkte til syne i kroppens fysiske udtryk, sammen med de bevidste eller ubevidste hæmninger og restriktioner, der er i personligheden den fysiske bevægelse bliver simpelthen et synligt udtryk for impulsens vej indefra og ud i bevægelse.

\section{Metodens 3 faser}

I sin brug af aktiv imagination i bevægelse arbejdede Whitehouse med 3 faser. ${ }^{20}$

Den første fase indledte hun med en Graham-inspireret gulvopvarmning. Whitehouse omdannede Grahams opvarmningsøvelser til en individuel fordybelse i kroppen, der trak den enkeltes opmærksomhed væk fra bevægelsens ydre form og ind i den kinæstetiske sansning af bevægelsen, som den føles indefra. Hun brugte således opvarmningen til at skærpe og forfine kontak- 
ten til impulser fra underbevidstheden, som hun mente var »buried in the body, in tissues, muscles, and joints... ${ }^{21}$

-... Efter opvarmningen, hvor Whitehouse havde fungeret som leder i gruppen, kom anden fase, hvor hun trak sig ud i hjørnet af lokalet og bad bevægerne finde et sted $\mathrm{i}$ rummet de gerne ville være, lukke øjnene, vende opmærksomheden indad og vente på at en indre impuls skulle dukke op i opmærksomheden i form af kropsfornemmelser, billeder, fantasier, stemninger, følelser eller hvadsomhelst andet. Og her kommer det afgørende i aktiv imagination: den imaginerende skulle med hele sin opmærksomhed gå ind i følelsen eller billedet knyttet til impulsen og igennem kroppen lade impulsen komme til udtryk i fysisk bevægelse i rummet.

»You follow it where it takes you, no matter how disorderly or how unrelated it seems. It will finally use everything that seems disorderly or unrelated to bring you to a new place. That is very much like the dreams and the active imagination of Jung. You learn to pay attention to a process in yourself that you do not control, that you do not manage «. ${ }^{22}$

Ved at følge impulsen så længe som muligt, uden selv at gribe ind i processen, opstod der på et tidspunkt uværgerligt en ny impuls, som bevægeren så kunne følge og lade komme til udtryk igennem bevægelsesprocessen. Der opstod herved en kontinuerlig række af improviserede bevægelser, som havde bevægerens egen indre virkelighed som udspring.

Den dionysiske arv fra Wigman ses tydeligt her $\mathrm{i}$ anden fase, hvor Whitehouse $\mathrm{i}$ bogstaveligste forstand opfordrer deltagerne til at lukke øjnene for den ydre verden med det formål at komme i kontakt med den indre. Og ekstasen, kontroltabet og overgivelsen til indre kræfter er også kvaliteter fra Wigmans expressive improvisatio- ner, som er genkendelige i Whitehouses brug af aktiv imagination.

Forskellen ligger nok mest i, at hvor Wigman brugte de expressive improvisationer til at lade det ubevidste komme $u d i$ fysisk bevægelse, søgte Whitehouse videre og så improvisationerne som en mulighed for at lade det ubevidste bevæge sig ind $i$ bevidstheden.

»Following the inner sensation, allowing the impulse to take the form of physical action is active imagination in movement, just as following the visual image is active imagination in fantasy. It is here that the most dramatic, psycho-physical connections are made available to consciousness $\ll{ }^{23}$

De »dramatiske psykofysiske forbindelser « mellem ubevidste impulser og deres fysiske bevægelsesudtryk forankrede Whitehouse yderligere $\mathrm{i}$ den danseterapeutiske proces' tredje fase, som involverede en verbalisering af de oplevelser, danseren havde haft under imaginationsfasen. Whitehouse tilstræbte her at forbinde oplevelserne $\mathrm{i}$ den indre verden til det, der foregik i danserens ydre verden, således at arbejdet med de indre processer kunne give styrke til livet i den ydre verden:

»Moments of insight, brought into focus by Active Imagination, have a natural effect on everyday life. They reveal a direction and show a development, acting as support and encouragement for what must be lived through, creating energy for a next step $\ll .^{24}$

\section{»Selv«og $» \operatorname{selv\ll }$}

Gennem aktiv imagination i bevægelse mente Whitehouse, at den enkelte både kunne frigøre sig fra fortrængte følelser, der levede en skyggetilværelse i kroppen og hindrede den indre impuls' frie bevægelse indefra og ud - og hun talte samtidig om, at den enkelte gennem aktiv imagi- 
Bevageren lukker фjnene og venter på en impuls, der bavager hende...

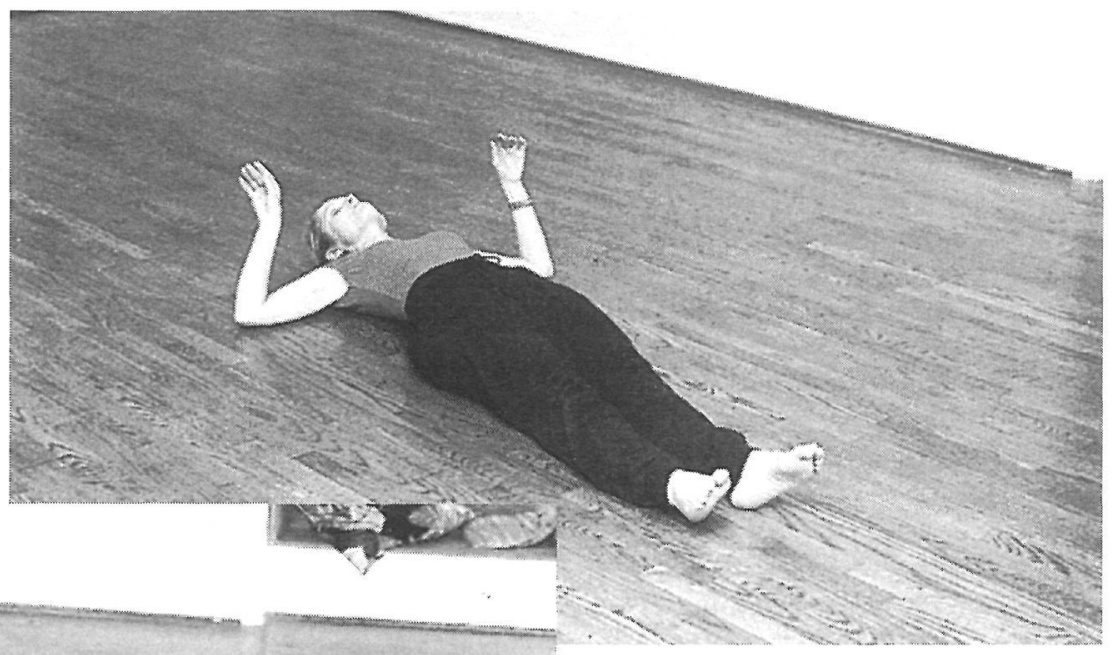

Idet hun lader bevagelsen udfolde sig....

Viser en skikkelse sig fra en drøm, hun havde for nylig
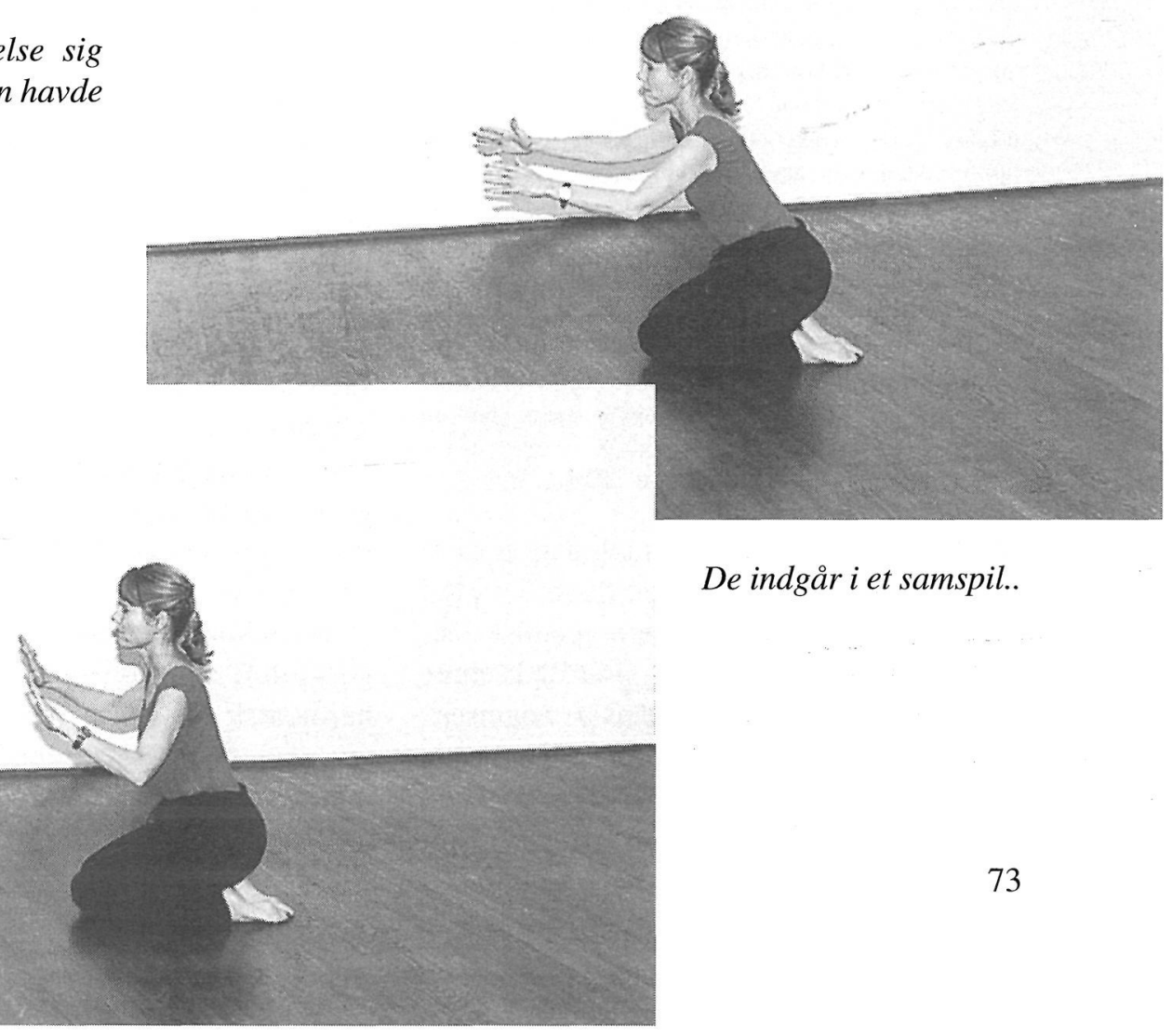

De indgår $i$ et samspil.. 
nation kunne komme i kontakt med impulser fra endnu dybere lag i sig selv:

"The levels they come from are not always personal levels; a universal connection with something much deeper than the personal ego is represented.$^{25}$

Dette meget dybere lag, som Whitehouse søgte at etablere en forbindelse til, er Selvet. Selvet er en specifik jungiansk definition af personlighedens totalitet, som udgør og rummer alle aspekter af psyken, hvoraf Mary Whitehouse beskæftigede sig med Jungs helt overordnede bevidsthedskategorier: det personlige og det kollektive.

Det personlige lag kaldte hun for $\gg$ det lille selv«, der udgøres af det indhold, som er knyttet til egoet og af egoet fortrængt til det personligt ubevidste.

Det kollektive lag var dét meget dybere niveau i den enkeltes personlighed, som er typisk for alle mennesker og som en fællesmenneskelig urgrund forbinder det enkelte menneske med menneskeheden:

»Because of depth analysis, I came to see and feel C.G. Jung's distinction between the many aspects of a human being, without his forgetting for a moment the wholeness of each one. It is a wholeness consisting of totality, completeness. Most people say »self « using the small letter »s « to mean the ego, the individual, the personality. The world of the self is the world of the Me and all its concerns.

Jung says »Self« with a capital »S « meaning also the world of the transpersonal, a world greater than the individual, more powerful than the ego. The Self is the totality of aliveness; it is wholeness, known and unknown, good and evil. If this idea lies at the bottom of danceteaching, then it becomes a primary value, leading directly to another - that of self-knowledge $\ll .{ }^{26}$

Whitehouse brugte aktiv imagination til at åbne for impulser fra begge disse lag i det ubevidste, der i den danseterapeutiske situation kunne blive bevidstgjort og komme autentisk til udtryk i kroppens bevægelser.

Autentisk bevægelse var for Whitehouse derfor ikke et spørgsmål om at lære nogen noget om en bestemt form for autentisk bevægelse eller autentisk adfærd - det var et spørgsmål om at lære at lytte til sig selv (læs: sit Selv) og tilegne sig en attitude overfor dybderne i sit indre liv, som hun kaldte ærlighed - en ærlighed, der ikke dirigerer eller styrer, men som tålmodigt venter og tillader de indre impulser at bevæge sig fra de dybeste lag af det ubevidste og ud i fysisk bevægelse ${ }^{27}$.

\section{Kroppens tao}

»...Polarity is present in the physical body, through the personality into all the pairs of opposites including conscious and unconscious. Life is never either/or, it is always the paradox of both/and. $\ll^{28}$

»Kroppens tao« fra 1958 var titlen på en af de tidligste artikler, Mary Whitehouse skrev om sit arbejde. Titlen peger på et grundlæggende filosofisk aspekt af hendes arbejde: tao.

I taoismen ses verden som gennemstrømmet af kraftlinier af »chi«, der kan forstås som en universel energi, som vibrerer i en spændingstilstand mellem to gensidigt forbundne, fundamentale kræfter i universet: yin og yang. Chi'en gennemstrømmer hele universet og kondenserer i fysisk materie, f.eks. i kroppen, hvor den flyder igennem meridianerne og dér følger spændingstilstanden mellem yin og yang i kroppen. Kroppen bliver i den taoistiske forståelse til et levende, vibrerende energifelt, der enten kan være »i tao« dvs. i en harmonisk vekselvirkning mellem yin og yang eller »ude af tao«, en tilstand, hvor den dynamiske spændingstilstand mellem polariteterne er ude af ligevæg ${ }^{29}$.

Whitehouse brugte danseterapien til, gennem fysisk bevægelse at genetablere en harmonisk balance mellem polariteterne yin og yang i personligheden: hendes konkrete udgangspunkt var, at enhver fysisk 
handling kræver aktivitet fra to sæt modsatrettede kræfter, der må arbejde sammen helt ind $\mathrm{i}$ muskulaturen for at bevægelse kan foregå. På denne måde så hun polaritet indbygget $\mathrm{i}$ kroppen som et grundlæggende mønster i bevægelse ${ }^{30}$.

Der er her tydelige spor fra træningen hos Graham, der havde indkorporeret de mange dynamiske modsætningspar i kroppen $\mathrm{i}$ sine to universelle bevægelses-principper $»$ contraction $\ll$ og $»$ release $\ll .{ }^{31} \mathrm{Og}$ allerede Graham havde brugt contraction og release $\mathrm{i}$ en taoistisk sammenhæng - som på een gang dybdepsykologiske polariteter og sproglige begreber for de universelle kræfters bevægelse $\mathrm{i}$ forhold til Hara - dét center i maven, som i den taoistiske filosofi udgør sindets sæde. ${ }^{32}$

Den anden kilde til »kroppens tao« er uden nogen tvivl Jung's store vægtning af polaritetsbegrebet. I sin bestræbelse på at forstå mennesket i sin helhed arbejdede Jung som regel med komparative kulturpsykologiske analyser, der blandt andet også omfattede taoismen. Og dynamikken mellem personlighedens polariteter og polariteternes forening $\mathrm{i}$ en højere enhed var et så omfattende princip i Jungs menneskesyn, at det direkte er indskrevet $i$ hans opfattelse af psyken som et »complexio oppositorium - et kompleks af modsætninger. ${ }^{33}$

I sit arbejde opfattede Whitehouse polariteter som meget mere end kroppens fysiske funktionsmåder og pegede på, at dét, at arbejde bevidst med bevægelsernes polariteter skal forstås i en større sammenhæng end den fysisk funktionalistiske - en sammenhæng, der kan rumme de betydninger af erkendelsesmæssig art, som opstår i det danseterapeutiske arbejde:

»...these exercises bring us from simple recognition of physical opposites into a larger framework, that of self-knowledge, a sense that the opposites mean more to us, individually, than mere physical conditions with which to work «. ${ }^{34}$

»Explore the continuum consisting of up and down«er et eksempel på een af Whitehouses helt enkle improvisationer, der ganske enkelt er bygget på en udforskning af polariteterne »op« og »ned «, som mellem sig åbner et felt af muligheder. Den ene ende af skalaen eksisterer ikke uden den anden - tværtimod er den ene forudsætningen for den anden. ${ }^{35}$

Polaritetsbegrebet beskriver således modsætninger, som ÅBNER noget imellem sig - som rummer en relation mellem sig og giver spændvidde til forskellige oplevelser på en skala i kontrast til dualitet, der beskriver et modsætningsforhold uden forbindelse mellem polerne. Set fra et bevægelsesmæssigt synspunkt virker dualitet som det rene vås - det er jo ganske enkelt umuligt at skære forbindelsen mellem op og ned over - eller mellem sammentrækning og udvidelse - eller mellem udad og indad...

I kroppen bliver taoismens begreber til hudnær virkelighed, hvilket een af Whitehouses professionelle elever, den analytiske psykolog og danseterapeut Joan Chodorow erfarede under sin terapeut-træning hos Whitehouse. Hun omtaler simpelthen sin tid hos Whitehouse som en vej gennem dynamiske spændinger mellem indbyrdes afhængige modsætninger - en »fuld kropslig erfaring af tao ${ }^{36}$

\section{At bevage sig og at blive bevaget}

Det helt centrale i Whitehouses arbejde med aktiv imagination i bevægelse bestod $\mathrm{i}$ at knytte forbindelsen mellem de bevægelser, som er styret af bevidstheden og de bevægelser, der kommer fra det ubevidste. 
Joan Chodorow fortæller, at hun i sin første tid hos Mary Whitehouse brugte meget mere tid på at vente på bevægelsen end på at bevæge sig. Hver gang bun gik ud på gulvet og begyndte at bevæge sig kom der et »Nej!« - så ventede hun lidt og begyndte på ny at bevæge sig, kun for at høre endnu et »Nej!«-

»... this happened so many times that I did much more waiting than moving. Then, I gradually realized that I could truly let something happen. I didn't have to form the movement consciously. It had its own form «. ${ }^{37}$

Chodorow var på daværende tidspunkt selv professionel balletdanser og underviste dagligt $i$ ballet. Hun var vant til at arbejde bevidst med bevægelse, vant til en tekniktræning, der focuserede på et perfektioneret bevægelsesmønster og vant til at få kroppen til at bevæge sig på dén måde, hun ville have den til. Hun var vant til at bevæge sig. - Og dét var netop Mary Whitehoues erfaring, at dansere generelt er trænet $\mathrm{i}$ at bevage sig:

"I move " is the clear knowledge that I, personally, am moving. I choose to move, I exert some demand on my physical organism to produce movement...Dancers are terribly familiar with »I move«; they are accustomed to think they do it all, that they must exert effort for each thing they want to have happen ${ }^{38}{ }^{38}$

Den lidt negative tone i citatet rummer Whiteouses kritik af dén holdning, at man skal yde, kæmpe, klare, overvinde og kontrollere sig selv (sit Selv/sin krop) for at fungere i samfundet. Hun mente, at denne holdning var så almindelig $\mathrm{i}$ den vestlige kultur, at hun omtalte sine, socialt set, velfungerende klienter som »normalt neurotiske«:

»...functioning and what are called normal..(they) have just as many if not as flagrant ${ }^{39}$ problems as people in hospitals. It is only that they manage their lives with »quiet desperation « instead of being markedly cut-off from the rest of the world..$^{40}$
Med inspiration fra Freud kunne man se denne stille desperation hos $\gg$ helt almindelige mennesker « som en tavs kulturneurose, der normaliserer sublimeringen af indre impulser og netop derved fikserer den enkelte i en kontrolleret, udadvendt gøren, som forrykker både dynamikken $o g$ balancen mellem polariteterne i personligheden. Man kunne sige, at vores kultur mere er $\gg \mathrm{i}$ gøren $\ll$ end »i tao«.

Mary Whitehouse søgte at integrere den ensidige, udadvendte gøren i Selvet. Hun talte om betydningen af oplevelsen af at blive bevaget:

»The moment when »I am moved « happens is astonishing both to dancers and to people who have no intention of becoming dancers. It is a moment-when the ego gives up control, stops choosing, stops exerting demands... it is a moment of total surrender that cannot be explained, repeated exactly, sought for or tried out...This is humbling and freeing for the personality that demands perfection, control, conformity - all the ills of our social training «« ${ }^{41}$

Hos Wigman havde Whitehouse arbejdet under devisen: »Nicht mehr selbst sich bewegen, sondern bewegt werden ${ }^{42} \ll$. Whitehouse integrerede »bewegt werden « med aktiv imagination, men hun tilstræbte aldrig Wigmans totale kontroltab eller det fuldstændige fravær af egobevidsthed. ${ }^{43}$ Tværtimod søgte hun at forandre kvaliteten af egoets deltagelse i bevægelsen fra en kontrollerende og dirigerende til en mere rummende og samarbejdende deltagelse, der lader de ubevidste impulser dukke op i kroppen og forme bevægelsen i modsætning til at gøre den:

»...one has to learn to let it happen as contrasted to doing it... The ego learns slowly an attitude toward what wants moving...Movement, to be experienced, has to be found in the body, not put on like a dress or a coat $\ll .{ }^{44}$ 


\section{Ikke enten-eller men både-og}

For at skabe ligevægt til den udtalte dyrkelse-af »I move«-polariteten i den vestlige verden arbejdede Whitehouse $\mathrm{i}$ praksis mest med »I am moved«-polen. Det var hendes holdning, at den kreative proces involverer både bevidste og ubevidste processer og at det er nødvendigt $i$ en fuld menneskelig udvikling at integrere begge ender af skalaen. ${ }^{45}$

I »Kroppens tao« understreger Whitehouse vigtigheden af leve med begge oplevelsestilstande:

»For example, some people are cut off from the unconscioussness. They are happiest doing planned, structured exercise. »I move « is all they know. At the other end, there are those who live their lives in an unconscious haze. These people may be able to improvise, but it looks vague, curiously disembodied, as if no one is doing it...as if it is happening by itself. The experience of »being moved« is all they know «. ${ }^{46}$

Whitehouse satte bevægelsesbegreberne »I move « og »being moved « ind i den taoistiske referenceramme, hvor hun så dét at udvikle balance mellem polariteterne som en åbning til at leve fra en opmærksomhedstilstand uden dualitet, men med friheden til at bevæge sig mellem polerne uden at være begrænset til een af dem: »...This is the ideal - it is what is meant by both/and instead of either/or $\ll .{ }^{47}$

Hun kaldte denne opmærksomhedstilstand for »detachment «, et taoistisk begreb, der $\mathrm{i}$ vestlige sammenhænge ofte fejlagtigt oversættes med associationer til verdensfjernhed, afsondrethed eller ligegyldighed. ${ }^{48}$ Som jeg ser det, er »detachment « en tilstand, der åbner for at involvere sig i alle aspekter af tilværelsen uden at blive fanget i en ensidig tilknytning - »attachment« og uden at bide sig fast $\mathrm{i}$ den ene ende af godt og dårligt, sym- og antipati, lykke og lidelse og alle de andre dualistiske modsætningspar.

Mary Whitehouse sagde om mennesker, der oplever tilværelsen fra et niveau af detachment:

»...it is not that they do not suffer, but they know suffering is not the only thing; its opposite is also there. It is not that they do not enjoy; they know there is suffering. Finally, if they are lucky, they can contain, be aware of, both of these af once. Then something new is created; it is like the differing qualities of left and right; a third is found $\ll .{ }^{49}$

\section{Autentisk bevagelse}

»Autentisk bevægelse« er i Whitehouses forstand dén tredje kvalitet, der opstår i dét øjeblik personligheden er parat til at rumme både at bevæge sig og blive bevæget:

»The core of the movement experience is the sensation of moving end being moved. Ideally both are present in the same instant and it may litterally be and instant. It is a moment of total awareness, the coming together of what I am doing and what is happening to me $\ll .50$

Autentisk bevægelse er en højere enhed af, hvad jeg gør - min gøren - og hvad der sker med mig - min væren - i et øjeblik at total tilstedeværelse.

Jeg fortolker Mary Whitehouse derhen, at den autentiske bevægelsesoplevelse er en tilstand, hvor grænserne mellem egoet og underbevidstheden overskrides i et øjeblik, hvor egoet hverken er fraspaltet kontakten til underbevidstheden, som i den ensidige »I move«-tilstand og heller ikke absorberet i en ubevidst tåge, som i den ensidige »being moved «-tilstand. Men netop en tredje tilstand, hvor egoet aktivt samarbejder med og tillader impulser fra det ubevidste at bevæge sig i en krop, der kan rumme, give form til og strukturere autentiske udtryk for sine indre impulser. 
At autentisk bevægelse i Whitehouses definition således både rummer bevidste og ubevidste kvaliteter kan fortolkes udfra en tidsmæssig betragtning om, at i dét unikke øjeblik, hvor de ubevidste impulser træder ud i bevægelsen og ind i bevidstheden bliver både det bevidste og det ubevidste forandret: det, der før var i det ubevidste er ikke længere ubevidst, men derimod bevidst - og det bevidste ego er ikke mere det samme som det var lige før, eftersom noget nyt er blevet del af den bevidste helhed. Der er sket en transformation af begge dele og dermed af hele personlighedens struktur.

Denne integration af egoet og det ubevidste $i$ en højere enhed opstår i kraft af detachment: når egoet under den aktive imagination bliver mere og mere i stand til at slippe tilknytningen til sine vante bevægelsesmønstre opstår muligheden for, at nye bevægelser kan vokse frem og få adgang til bevidstheden.

Detachment skal således på een gang forstås som dén ideelle tilstand, der rummer polariteterne, men samtidig også som dén tilstand, der forudsætter den kreative, nyskabende bevægelse mellem polariteterne: at det ubevidste overhovedet kan få adgang til bevidstheden, ved at egoet under første halvdel af aktiv imagination lader vare med at gøre noget.

\section{At blive synlig}

Den sammenhæng, der vokser frem er en sammenhæng mellem en indre tilstand og dens synlige udtryk i omverden. Indtil nu har perspektivet hovedsageligt været at se bevægelserne indefra, fra dén, der oplever bevægelsen i sin egen krop. Mary Whitehouse beskrev også autentiske bevægelser set udefra:
»When the movement was simple and inevitable, not to be changed no matter how limited or partial, it became what I called authentic; it could be recognized as genuine, belonging to that person. Authentic was the only word I could think of that meant truth - truth of a kind unlearned but there to be seen at moments «. ${ }^{51}$

Modsætningen til autentiske bevægelsers synlighed blev for Whitehouse usynlighed. I sit arbejde med at hjælpe klienterne med at udvikle alle deres potentialer og komme i kontakt med alle områder af sig selv, blev hun opmærksom på, at det var som om nogle dele af kroppen kunne være helt forladte, helt uden opmærksomhed:

»...one quickly runs into their lack of awareness in certain areas; they have thrown whole parts of themselves away. These are the invisible parts; no matter how much movement takes place there is a queer effect - it does not show in a genuine way, it is invisible. Not until these areas are brought into conscious belonging can their movement become authentic and the invisiblility disappear. We are faced with a pair of opposites again - authentic as opposed to invisible «. 52

De usynlige bevægelser kommer fra forkastede områder i kroppen, der ikke er inddraget $\mathrm{i}$ bevidstheden - de er usynlige for bevidsthedens $\varnothing j$ e, hvilket jeg tolker derhen, at de usynlige områder er ikke-integrerede områder af Selvet, fortrængte potentialer i det personligt ubevidste, som ikke er integreret $i$ bevidstheden og som derfor ikke kan komme autentisk til udtryk, før de får opmærksomhed og bliver del af den bevidste personlighed.

Mary Whitehouse introducerer her sin forståelse af autencitet, som forudsætter bevidsthed - man er først autentisk, når dét man gør, er udtryk for noget, man véd at man er.

Og man er ikke autentisk når dét mán gør, er udtryk for noget, man ikke ved at man er. Autentisk handlen forudsætter altså bevidsthed, hvilket leder Mary Whitehouse til en noget speciel opstilling af modpolen 


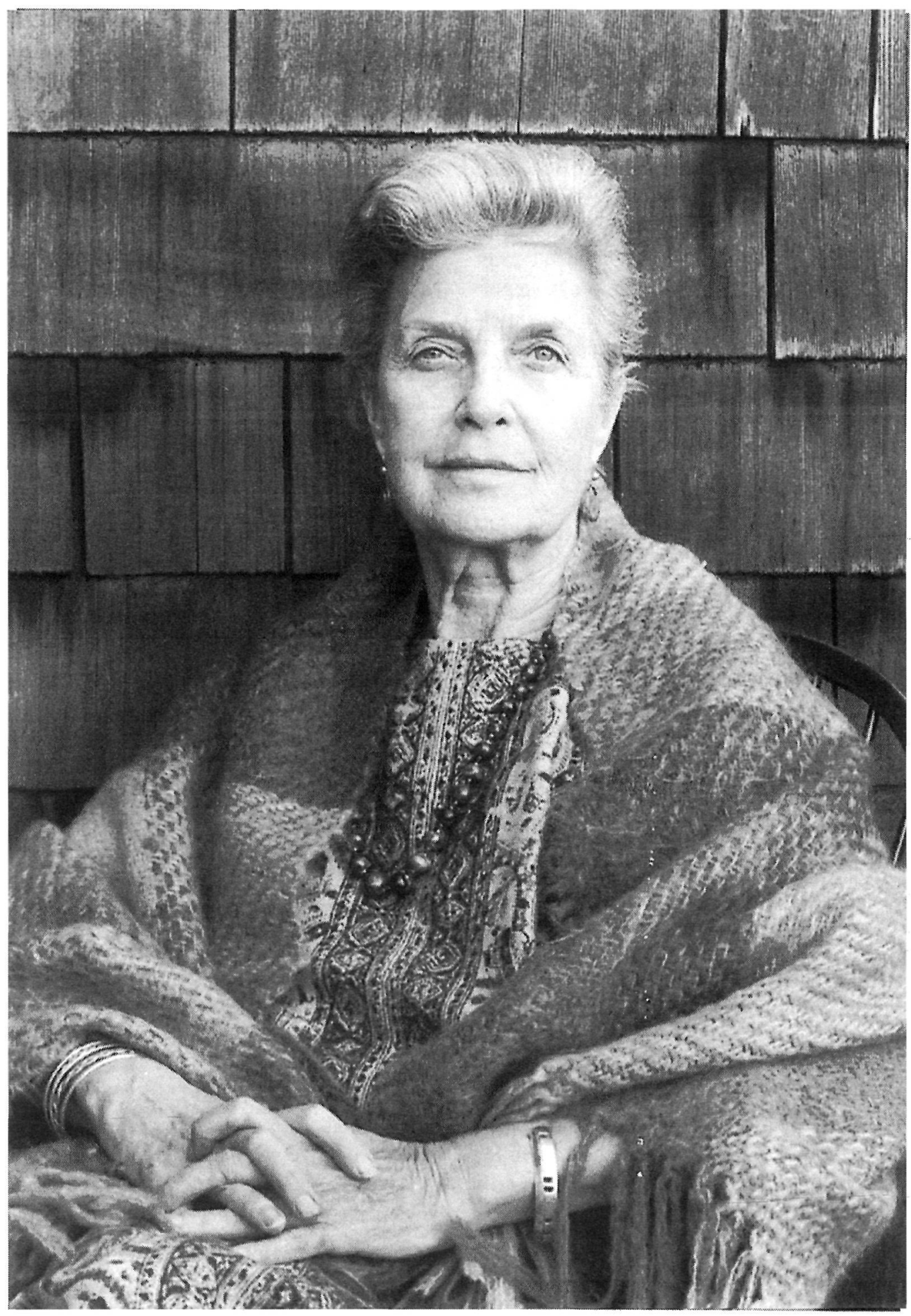

Mary Starks Whitehouse, 1978 (fra Chodoru 92). 
til autencitet: hun siger IKKE u-autentisk eller u-ægte, men u-synlig og u-bevidst.

De usynlige potentialer i de områder af sig selv, som bevægeren havde forkastet, kan IKKE komme autentisk til udtryk førend egoet åbner for dem og tillader sig at blive bevæget af dem. Indtil da bevæger de sig som fortrængninger i det personligt ubevidste, hvorfra de styrer med en $\gg s æ r$ effekt « - en sær effekt, der bliver bevægelsernes fysiske udtryk for kollisionen mellem egoet og de naturlige impulser fra Selvet på deres vej indefra-ud.

\section{Autentisk Bevagelse - en vej til Selvet}

Selvet kommer altså autentisk til syne i bevægelsernes udtryk indenfor alle de områder af personligheden, som ER integreret $\mathrm{i}$ bevidstheden.

At blive autentisk er således for Mary Whitehouse at blive bevidst om sig selv, at lære sig selv at kende - at tilegne sig sit Selv, som er dén livslange udviklingsproces, Jung kaldte for individuationen:

»Individuation betyder: at blive til enkeltvæsen (individ) og, for så vidt som vi ved individualitet forstår vor inderste, sidste og uforlignelige egenart, at blive til éns eget Selv. Man kunne derfor også oversætte individuation med $»$ Selvvirkeligg ørelse $\ll .53$

Individuationen er en proces, der på een gang gør mennesket til et unikt, selvstændigt individ - med Jungs egne ord: »til det bestemte enkeltvæsen, det nu engang er«, og til en bevist del af menneskeheden: »for så vidt som det menneskelige individ nu som levende enhed er sammensat af lutter universelle faktorer, er det fuldstændig kollektivt og står derfor ikke i nogen som helst modsætning til kollektiviteten ${ }^{54}$

Den individuelle udfoldelse af denne autentiske fællesmenneskelige forbundethed var for Mary Whitehouse i sig selv en autentisk bevægelse.

Hele den danseterapeutiske proces kan derfor med hendes egne ord beskrives som

»...Tao, a way, a becoming, Movement, as I see it now touches people in their lives. It opens up their individual sense of themselves and teaches them that they are humanly valuable to each other...Being is the essence, becoming is the movement of the essence. After all, it is Life that dances «. 55

\section{Sammenfatning}

»Autentisk Bevægelse« var en titel, Mary Whitehouse gav sin arbejdsmodel - det var også en betegnelse for hele den danseterapeutiske proces, hvor bevægerens indre impulser kommer direkte, fysisk, sanseligt-og synligt til udtryk i kroppens bevægelser. Og det var betegnelsen for en indre oplevelse af autentisk bevægelse, en væren i bevægelse, en form for tilblivelse. »Autentisk Bevægelse « skal altså forstås på mindst 4 leder;

1. som titel på en hel danseterapeutisk model, hvilket involverer alle lagene i modellen, såvel filosofiske, teoretiske og metodiske aspekter

2. som en autentisk bevagelse inde i kroppen med retning indefra-ud, hvor bevægeren bliver opmærksom på indre impulser og tillader impulserne at udtrykke sig i bevægelse, hvoraf følger

3. at kroppens bevægelser, set udefra, bliver autentiske udtryk for at impulsens bevægelse indefra-ud er forløbet uden hindringer - at kroppens ydre bevagelser bliver autentiske udtryk for indre bevagelser

4. som en autentisk proces $i$ personligheden: individuationen, der gradvist ophæver modsætningerne mellem bevægelsesimpulserne fra egoet og det 
ubevidste i en højere enhed, der forener dét, bevægeren bevidst gør, når han/hun bevager sig med dét, der sker indefra, når bevægeren tillader sig at blive bevaget af impulserne fra det ubevidste.

\section{Noter}

1. Mary Whitehouse in Frieda Sherman, Conversation with Mary Whitehouse, Pre-conference Seminar, American Journal of Dance Therapy, fall «winter, 1978

2. Danseterapien kan spore sine bevægelseskulturelle rødder til den moderne dans' fremvækst $i$ begyndelsen af århundredet. I danseterapeutisk litteratur nævnes »danseterapiens 6 pionéerer«: Mary Whitehouse, Trudi Scoop, Liljan Espenak, Blance Evan, Alma Hawkins og Marian Chase. De var alle moderne dansere, der via deres arbejde som professionelle kunstnere og undervisere hver for sig opdagede forskellige psykoterapeutiske potentialer i moderne dans. Kombineret med teoretisk inspiration fra bl.a. psykoanalyse, kropsterapi, humanistisk psykologi og jungiansk psykologi udviklede pionéerene i løbet af 1940'erne og 50'erne forskellige veldefinerede danseterapeutiske modeller for arbejdet med menneskelig vækst og personlig udvikling gennem bevægelse.

Pionéerernes arbejdsmodeller har dannet grundlag for danseterapiens udvikling som profession og som universitetsfag på alle akademiske niveauer $\mathrm{i}$ USA. Se foreksempel Fran Levy: »Dance movement therapy - a healing art «, 1988.

3. Anderson, 1986, p.155 samt Levy, 1988, p.3

4. Mary Whitehouse, 1979 , p. 52

5. John Martin, Modern Dance, 1933/1972, pp.5660 , in Levy, 1988, p.4-5 (min fremhævelse)

6. Whitehouse, 1979, p.52

7. Levy, 1988, p.61

8. Mary Whitehouse, 1979 , p. 51

9. Mary Whitehouse, 1979, p. 53

10. Mary Whitehouse, 1969 , p. 62 , her fra Wallock, Reflections on Mary Whitehouse, 1981, p. 45

11. Mary Whitehouse, 1979 , pp. 52-53

12. Whitehouse $\mathrm{i}$ et interview med Wallock, 1977 , p.69, her fra Wallock, 1981, p.46

13. Mary Whitehouse, 1963, p. 3, her fra Joan Chodorow, 1991, p. 28
14. Mary Whitehouse, 1979, p.58

15. Sigmund Freud, Drømmetydning 1 og 2, 1960, pp. 90-91, her fra Ole Vedfeldt, Drømmenes Dimensioner, 1991, pp. 17-18

16. Ole Vedfeldt, 1991, p. 67

17. Ole Vedfeldt, 1991, .p. 94

18. Jung, 1935, p. 173, fra Chodorow, 1992, p. 134135

19. Whitehouse, 1979 , p. 59

20. Wallock, Reflections on Mary Whitehouse, 1981, pp.50-52

21. Wallock, 1977, p. 50, Levy, 1988, p. 65

22. Mary Whitehouse in Wallock, 1977, p. 71/Wallock, 1981, p.51

23. Mary Whitehouse, 1963, p. 3, her fra Joan Chodorow, 1991, p. 28

24. Whitehouse, 1979, p. 59

25. Mary Whitehouse, 1979 , p. 58

26. Mary Whitehouse, 1979 , p. 54

27. Mary Whitehouse, 1958, p. 10, her fra »Gestaltung in tanz und Gymnastik«, 1987, p. 186

28. Mary Whitehouse, 1979 , p. 55

29. Arnold Mindel, Dreambody, p. 17

30. Mary Whitehouse, 1979 , p. 55

31. Aschengreen, 1992, p.44

32. Whitehouse, med reference til Karlfried Durckheim: »Hara, The Vital Centre of Man«, New York; Fernhill, 1970

33. Beskrivelsen af modsætningskomplekset er hentet fra Chodorow, 1992, p. 119. Dette begreb synes at træde i kraft som erstatning for den begrebsmangel, som Jung beklager $\mathrm{i} »$ Jeget og det ubevidste $«$ : »Desværre har vor vesterlandske ånd, som følge af sin mangel på kultur...ikke engang fundet et begreb, endsige da et navn, for modsætningernes forening på en mellemvej, dette mest fundamentale element $\mathrm{i}$ den indre erfaring - et begreb eller et navn, som man med rette kunne sidestille med det kinesiske tao«, p.112.

34. Mary Whitehouse, 1979 , p. 56 
35. Whitehouse, 1979 , p.66

36. Joan Chodorow, 1991, p. 26

37. Joan Chodorwo, 1991, p. 25

38. Mary Whitehouse, 1979, p. 57

39. flagrant = åbenbare

40. Mary Whitehouse, 1979 , p. 51

41. Mary Whitehouse, 1979, p. 57

42. Mary Wigman, Die Sprache des Tanzes, p. 39, her fra Gestaltung in Tanz und Gymnastik, Bremen, 1987 , p. 50

43. Denne konklussion drages af Fran Levy i hendes Whitehouse-biografi, hvor hun problematiserer forholdet mellem $» I$ move $« / \ll b e i n g$ moved « begreberne hos Whitehouse, Levy, 1988, p.68

44. Mary Whitehouse, 1963, pp. 4-6, her fra Joan Chodorow, 1991, p. 27

\section{Litteraturliste}

Chodorow, Joan (1978) (1991) »Dance Therapy and Depth Psychology«, Routledge, New York

- (1992) »Danseterapi og dybdepsykologi - Fantasi i bevægelse «, Hans Reitzels Forlag A/S, København

»Gestaltung in Tanz und Gymnastik « (1987) Sportswissentschaftlische Universität, Bremen

Houmark, Pia (1994) »Jung-inspireret danseterapi en vej til personlig udvikling«, speciale i hum. samf. Idræt ved Københavns Universitet

Jung, Carl Gustaf (1989) »Jeg'et og det ubevidste, Gyldendal

Levy, Fran. J. (1988) »Dance movement therapy - a healing art«, Reston, Virginia, National Dance Association, AAHPHERD

Mindell, Arnold (1984) »Dreambody - the body's role in revealing the self $«$, Routledge \& Kegan Paul, London

Vedfeldt, Ole (1991) »Drømmenes dimensioner«, Gyldendalske Boghandel, Nordisk forlag A.S, Copenhagen
45. Mary Whitehouse, 1979 , p. 55

46. haze = tåge, Mary Whitehouse, 1958, pp. 11-13, her fra Joan Chodorow, 1991, p. 28

47. Mary Whitehouse, 1979 , p. 58

48. John Engelbrech har foreksempel talt om »hellig nøgternhed « som en tilstand hinsides sympati og antipati, bilag til »Gymnastradaen som kulturfaktor «, 1987

49. som foregående, min kursivering

50. Mary Whitehouse, 1958, p. 4, her fra Joan Chodorow, 1991, p. 28

51. Mary Whitehouse, 1979, p.57

52. Mary Whitehouse, 1979, p. 57

53. Jung, Jeg'et og det ubevidste, p. 73

54. Jung, Jeg'et og det ubevidste, p. 74

55. Whitehouse, 1969 , p.64

Wallock, Susan Frieder (1981) »Reflections on Mary Whitehouse«, American Journal of Dance Therapy, volume 4, no.2, pp.45-56

Whitehouse, Mary Starks (1958) »The Tao of the body «, paper presented at the Analytical Psychology Club of Los Angeles, 1958

- (1969) »Reflections on a metamorphosis« in »A well of living waters - Festschrift für Hilda Kirsch«, ed. R.Head, et al., pp.272-7. Los Angeles, C.G. Jung Institute, 1977

- (1978) »Five Dance Therapists Whose Life and Work Have Been Influenced by the Psychology of C.G. Jung « in: American Journal of Dance Therapy, fall/winter 1978, pp.17-18

- (1979) »C.G. Jung and dance therapy - two major principles« in Penny Lewis Bernstein, (Ed.), »Eight theoretical approaches in dance-movement therapy«, Dubuque: Kendall/Hunt, pp.51- 70 